\title{
Golden 5 elkarbizitza programa: aritutako irakasleen ikuspegia
}

\author{
Golden 5 coexistence program: \\ the perspective of the teachers who have applied it
}

\author{
Sara Gaskue*, Alex Ibañez-Etxeberria \\ Hezkuntza, Filosofia eta Antropologia Fakultatea, \\ Euskal Herriko Unibertsitatea, Donostia, Gipuzkoa
}

\begin{abstract}
LABURPENA: Egungo hezkuntzak aniztasunari, gatazkei eta ikasleen errendimendu zein motibazio hobekuntzari erantzuna emateko erronka du eta hori gainditzeko modurik onena prebentzioa da. Horretarako, ezinbestekoa da eskolan elkarbizitza positiboa izatea eta zeregin horretan irakasleek laguntzailetzat izan dezakete Golden 5 elkarbizitza programa. Bertan gelaren kudeaketa, irakasle-ikasle harremanak, berdinen artekoak, ikaskuntza doitua eta irakasle-familia harremanak lantzen dira. Esan beharra dago nahiz eta urte batzuetan indarrean egon den, pixkanaka eskoletan presentzia galduz joan dela programa. Ikerketa honen bitartez, Golden 5 programarekin lan egindako irakasleek honen inguruan egiten duten balorazioa ezagutu nahi izan da. Horretarako, Haur Hezkuntzan, Lehen Hezkuntzan eta Derrigorrezko Bigarren Hezkuntzan lanean diharduten 7 irakaslerekin elkarrizketa erdiegituratuak mantendu dira eta irakasleek programaren inguruko ikuspegi orokor positiboa dutela eta honek parte hartzaile guztiengan eragin positiboak izan dituela azaleratu da. Halaber, ikusi ahal izan da nola eskoletan inplementazioa zailtzen duen ratio handia eta irakas-zama garrantzitsua izateaz gain, zentroen nahiz Berritzeguneen jarraipena falta izan den. Hala ere, indibidualki bada ere, egun programarekin lanean dihardute zenbait irakaslek.
\end{abstract}

GAKO-HITZAK: Golden 5, Elkarbizitza, Irakasleak, Ikasleak, Familia, Hezkuntza Sistema.

ABSTRACT: Today's education is challenged to respond to diversity, conflict, and both student performance and motivation and prevention is the best way to achieve it. For this purpose, it is essential to have a positive coexistence in the classroom, for which teachers can benefit from the Golden 5 coexistence program. The program works on classroom management, teacher-student relationships, peer relationships, adjusted learning and family-school relationships. It should be noted that although it has been on the rise for some years, this program has gradually lost its presence in schools. Through this research, we wanted to know how the teachers who have used the Golden 5 program value it. To this end, semi-structured interviews were carried out with 7 teachers working in Early Childhood Education, Primary Education and Secondary Education where a positive view of the programme by the teaching staff could be appreciated, as well as positive effects on all the participants. Likewise, it has been possible to observe how apart from having a high ratio and an important teaching load in the schools, there has been a lack of follow-up of the program by the centres and the Berritzegune, making difficult the implementation. Nevertheless, there are currently teachers who continue working with it even individually.

KEYWORDS: Golden 5, Coexistence, Teachers, Students, Family, Educational System.

\footnotetext{
* Harremanetan jartzeko / Corresponding author: Sara Gaskue. Euskal Herriko Unibertsitatea. Matematika, Zientzia Esperimental eta Gizarte Zientzien Didaktika. Hezkuntza, Filosofia eta Antropologia Fakultatea. Oñati plaza, 3 (20018 Donostia. Gipuzkoa). - sgaskue001@ikasle.ehu.eus - https://orcid.org/0000-0001-8177-5585

Nola aipatu / How to cite: Gaskue, Sara; Ibañez-Etxeberria, Alex (2021). «Golden 5 elkarbizitza programa: aritutako irakasleen ikuspegia». Tantak, 33(1), 137-163. (https://doi.org/10.1387/tantak.21929).

Jasotze-data: 2020/08/04; Onartze-data: 2021/02/16.

ISSN 0214-9753 - elSSN 2444-3581 / (C) 2021 UPV/EHU

(c) (i) $\odot$ Lan hau Creative Commons Aitortu-EzKomertziala-LanEratorririkGabe 4.0 Nazioartekoa

lizentzia baten mende dago
} 


\section{SARRERA: ESKOLA ETA ELKARBIZITZA}

Egungo gizartea kulturartekotasun, erlijio, nahiz maila sozial ezberdin askokoa da (INE, 2018). Azken finean, gizartea geroz eta pluralagoa da, aurrez aipaturikoaz gain, mugikortasun handiagoa eta familia eredu ezberdinak baitaude. Horrez gain, gertatzen ari diren aldaketen artean, demokrazia ohiko funtzionamendu bihurtzen ari da, honek, indarkeria desagerrarazteko giza eskubideekiko errespetua eta oinarrizkoak diren adierazpen, mugikortasun, erlijio, sinesmen, sexu... askatasunak errespetatzen dituelarik (Delval, 2013).

Egun, eskoletan gehiago oinarriturik, jazarpena hezkuntzan, nahiz gizarte eremuan ardura gehien sortzen duen gaietako bat bihurtu da, ikasleen garapen pertsonalean, sozialean, zein ikas garapenean dituen ondorio larriengatik. Euskadin 2018. urtean zehazki, tratu txarren indize orokorra \% 20,2koa izan zen Lehen Hezkuntzan eta \% 16,2koa Derrigorrezko Bigarren Hezkuntzan (ISEI-IVEI, 2019). Horrekin erlazionaturik, eskolek ikasleen jarrerak izan ohi dituzte ikas-irakaskuntzarako oztopo, eta ondorioz, lorpen akademiko baxua izan ohi dute ikasle horiek (Lera, Jensen, Josang et al., 2007c).

Hortaz, aipatu berri diren arazo edota egoera horiek, hainbat erronka ezartzen dizkiote egungo hezkuntzari: aniztasunari, gatazkei eta ikasleen errendimendu zein motibazio hobekuntzari erantzuna ematea (González, 2010). Erronka horiek gainditzeko modurik onena prebentzioa da, eta horretarako, eskolan elkarbizitza positiboa egotea behar-beharrezkoa da, hau da, indarkeriarik gabeko elkarbizitza izatea (Eusko Jaurlaritza, 2019). Beste era batera esanda, eskola erakunde bizidun bihur dadin, honek, ikasleak beren zein besteen burua eta ingurunea ezagutu eta horiekin harreman positiboak izateko gaitasuna garatzeko testuinguruak proposatu behar ditu. Horrez gain, horien inguruan hausnartzen lagundu behar ditu ikasleak. Horri jarraikiz, Delvalek (2013) adierazten du hezte prozesuan zehar ikasleei egoera aldakorretara moldatzen irakasteaz gain, hezkuntzaren helburuak zoriontasuna, autonomia, ardura eta bakea lortzea ere badirela, eta Hernándezen (2002) esanetan, irakaslearen rola jada ez da transmisiora bakarrik mugatzen: ikasleen formakuntza integralera bideratuta egon behar du. Egun dagoen afektibitate eta emozioen garrantziaren ikuspegiari loturik dago hori, kognitiboak afektiboa baldintzatzen duelarik, eta afektiboak kognitiboa.

Hortaz, une honetan, elkarbizitza lehentasunezko hezkuntza zeregin bihurtzeko beharra dago (Peñalva eta Soriano, 2011), eta hori, Oinarrizko Hezkuntzako curriculumean zehaztu eta Euskal Autonomia Erkidegoak (EAE) ezartzen duen 236/2015 Dekretuan (2016/01/15eko EHAA) finkatua azaltzen da. Bertan zehazten da ikasleak Oinarrizko Hezkuntza Orokorra amaitzean hezkuntza helburuak lortu eta bizitzako esparru eta egora guztietan moldatzen jakin dezan zer gaitasun izan behar dituen. Modu ho- 
netan, horien artean dagoen elkarbizitzarako gaitasuna zehazten da: «Pertsonen arteko, taldeko eta komunitateko egoeretan elkarrekikotasunez parte hartzea, eta norberari aitortutako eskubideak eta betebeharrak besteri aitortzea, norberaren zein guztion ongirako» (7.2.c. artikulua).

Elkarbizitzaren ikuspegi positiboa elkarbizitza demokratikoan oinarritzen da eta honek, bakearen kulturari erreferentzia egiteaz gain, botereabusua eta berdintasun ezaren aurka jokatuz, berdintasunezko eskola inklusiboa sortzea du helburu (Carbajal, 2013). Horretarako, beharrezkoa ikusten da ikasleengan oinarrizko trebetasunak garatzea, hala nola autokontzeptu eta autoestimua, autoezagutza emozionala, enpatia, komunikazio trebetasunak eta asertibitatea (Fernández, 2001).

Elkarbizitza positiboa eskolan edota gelan bertan barneratu ahal izatea irakasleen esku dago. Irakasleek ez badituzte paradigma berriak, aldaketa beharrak eta zergatia nahiz zertarakoa kontuan hartzen, ezinezkoa bihur daiteke hori (Delval, 2013; Lera, 2015b; Wentzel et al., 2010; Baña eta Zaitegi, 2016). Horretarako, Carmen Bañak Zaitegiri egindako elkarrizketan (2016) honek azaltzen du nola irakasleak akademikoki onak, batere kaskarrak ez, baina baita emozionalki onak, orekatuak eta gizarte-trebetasunak nahiz balio sendoak dituztenak izan behar diren. Gainera, lidergogaitasuna, lanbidearekiko, ikastetxearekiko eta ikasleekiko konpromisoa, lanerako grina eta etengabeko formakuntza erakutsi behar dute. Bestalde, beren praktika, arazoak eta baita emandako soluzioak aztertzeko ere gogoeta jarrera izan behar dute irakasleek. Peñalva, López eta Landak (2013) ere ikasleei hezkuntza emozionala eskaini eta trebetasun emozionalak gara ditzaten, irakasleak konpetentzia emozionaletan ondo formatuta egoteari garrantzia ematen diote.

Zenbaitetan ez da erraza izaten hezte prozesuarekin guztiz lotua dagoen elkarbizitza helburu horiek aurrera eramatea, eta horretarako, baliagarriak izan ohi dira programak. EAEn zehazki, Eusko Jaurlaritzak 2012. urtetik, Golden 5 elkarbizitza programa (Lera, 2009) bultzatu du, baina 2018. urtetik aurrera, honen presentzia eskoletan gutxituz doa.

\section{GOLDEN 5 PROGRAMA}

Mari Jose Lera psikologoa da Golden 5 programaren koordinatzailea. Programa, psikologian egindako aurrerapenetan oinarrituta dago, Europako Batasunak finantzatu zuen 2004 urtean, Europako hezkuntza arloko 10 praktika onenetako bat bezala hautatu zuten eta Europako Batzordeak brontze kategorian kondekoratu zuen 2009. urtean hezkuntza berrikuntza arloan. Gaur egun, Lituania, Polonia, Norvegia, Brasil, Espainia eta bereziki Euskal Herrian (200 zentrotik gora) ari dira edo aritu dira, ikuspegi berri horrekin lanean eta aipatzekoa da, Gazan irakasle eta orientatzaile taldeak hezten ari direla astero komunitatea sufritzen ari den traumatizazioa 
arintzeko (Lera, 2015b). Esan beharra dago, nahiz eta programa martxan jarri zenean Derrigorrezko Bigarren Hezkuntzan oinarrituz aplikatzen zen, gaur egun, Lehen Hezkuntzan eta Haur Hezkuntzan ere inplementatu ohi dela.

Hortaz, «Golden 5» programa eskola elkarbizitza hobekuntzarako programa bat da, hau da, eskola giro atseginagoa eta eraginkorragoa sortzekoa. Honen helburu nagusia, oraindik beren potentzialtasun osoa garatzeko aukera izan dezaketen ikasleei dirdira egin dezaten beharrezko trebetasunak eskaintzea da. Horrez gain, ikasleengan eskolako lanekiko motibazioa, zein beren garapen pertsonala hobetu nahi ditu. Gelaren osotasunera bideratuta dago, baina aldi berean, atentzio berezia ematen die behar berezia duten edota bazterketa sozialeko arriskuan dauden haurrei (Lera, 2015a).

Golden 5 programa hiru teoria klasikoetan dago oinarrituta: (1) irakasleen espektatibak (Rosenthal, 1991), (2) atribuzioen garrantzia (Heider, 1958; Weiner, 1985) eta (3) behatzaile efektua (Cottrell, 1975). Teoria horiei jarraikiz, irakasleak Golden ikasleekiko pertzepzio eta espektatibak alda baditzake, eta haien alderdi positiboak adieraziz erakuspen publikoak egiten baditu, segur aski taldea aldatuz joango da. Ondorioz, taldeak Golden ikasleekiko espektatibak aldatuz, behatzaile efektuak pertsona eta taldea aldatu ditzake. Horrela, Golden ikasleek espektatiba positiboagoei, sozialagoei eta bere garapenari dagozkionei erantzungo diete (Lera, Jensen, Josang et al., 2007c).

Horrez gain, pertzepzio sozial eta autopertzepzioan aldaketa gerta dadin, familiaren inplikazioa beharrezkoa da. Horren garrantzia oso handia da, eskolako lorpenen \% 23a familiaren babesarekin lor baitaitezke, betiere, familiari euskarri bat ematen bazaio (Berg, 2002). Gauzak horrela, eskolako partaide guztiek hartzen dute parte programan, hala nola ikasleek, gurasoek, irakasleek, eta zenbaitetan, elkarteek ere (Lera, 2009). Horrek garrantzia berezia du, nahiz eta irakasleak hartzen duen jarrera laguntzazkoa izan, eskolako gainontzeko partaideek ere programari euskarririk ematen ez badiote, indarra galduz joango baita (Lera, 2006).

Begirada aldaketa horrekin lanean hasteko eta irakaslearen lana gidatzeko asmoz, funtsezko urrats batzuk (helburua lortzeko eskaintzen diren estrategia batzuk) dituzten bost «Golden arlo» teorikotan banatzen da programa (Lera, Jensen, Josang et al., 2007d). Horiek, era sistematiko batean erabiliz, irakaslearen trebetasunak hobetzeaz gain, ikasleengan eragin zuzena dute (Lera, 2015a).

Ondorengo kontzeptu mapan (ikus 1. irudia), programa osatzen duten bost arlo edo alderdien helburuak azaltzen dira: «Gelaren kudeaketa» (Lera, Jensen eta Josang, 2007), «Harremanak eraikitzen» (Symanska eta Timmermansen, 2007), «Gizatiar giroa» (Buccoliero, 2007), «Ikasketa doitua» (Jensen et al., 2007a) eta «Familia eta eskolaren arteko harremana» (Jensen et al., 2007b). 


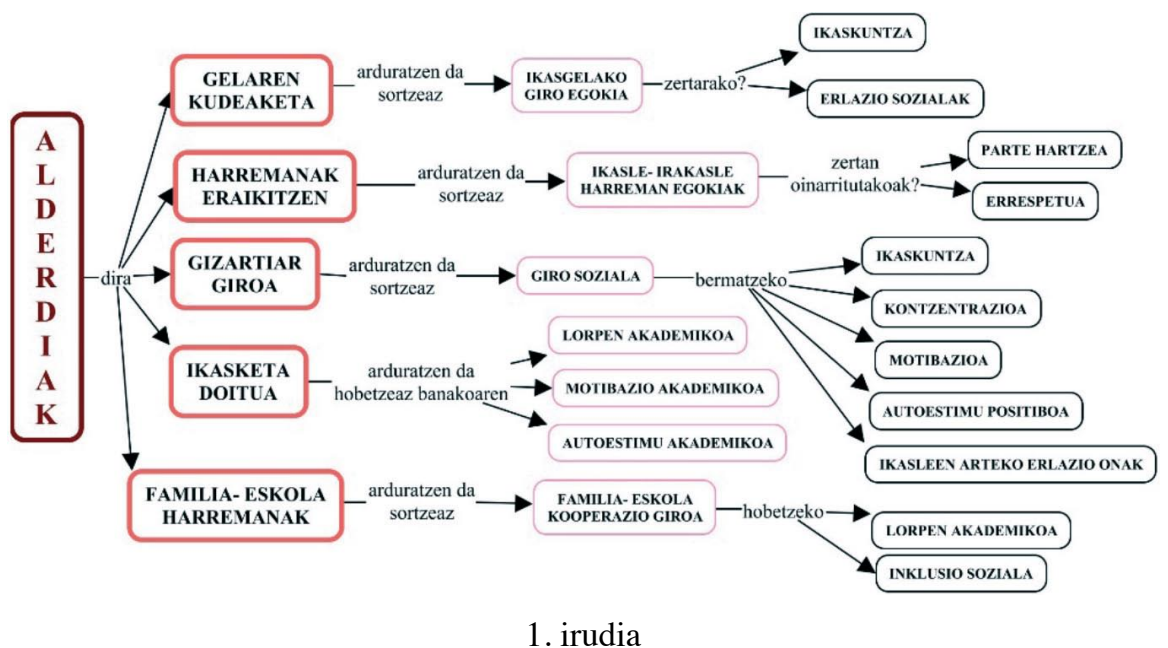

Golden 5 programaren 5 Alderdien Kontzeptu Mapa (Lera, 2009) lanetik egokitua

Alderdi horiekin lan egiteko, zenbait tresna proposatzen ditu programak (Lera, 2009). Jarraian azalduko diren hauek, hurrenkera honetan erabili beharko lirateke: lehenik, aurre egoera aztertzeko «Soziograma» (gelako erlazio mailak, nahiz bertan aurkitzen diren azpitaldeak ezagutzeko materiala) eta «Eskola eta ni» inkesta (5 Golden alderdiei dagozkion itemen bidez, horiek ebaluatzeko materiala) proposatzen dira, horrela egoeraren ebaluaketa kuantitatiboa eginez. Bigarrenik, prozesuan zehar erabiltzeko «Agenda» (programaren inplementazioa era antolatu batean eramateko materiala) proposatzen da. Azken honetan, astero, programak berak alderdi bakoitzerako proposatzen dituen funtsezko urratsetatik aukeratutako 5-6 urratsak, aste horretan lan egiteko hautatu diren 5 ikasle Goldenen izenak, horien inguruko oharrak eta aste amaierako ebaluaketa kualitatiboak egin daitezke.

Programaren inplementazio prozesua aurrera eraman duten irakasleekin egindako ikerketetan, irakasleek diote Golden 5ekin izandako esperientzia positiboa dela (Lera, Jensen, Josang et al., 2007b; Lera et al., 2006) eta programak eskainitako tresnak prozesuan zehar oso erabilgarriak egin zaizkiela (Lera, 2006; Lera et al., 2006; Gaskue, 2019) funtsezko urratsak erraz erabiltzeko aukera emanez (Lera, Jensen, Josang et al., 2007b).

Ondorengo tauletan ikerketa ezberdinetako irakasle, ikasle nahiz familiengan Golden 5ek izandako eragin eta zailtasun zehatzak ikus daitezke (ikus 1. eranskina). Aipatu beharra dago, prozesu honek traba batzuk izan ditzakeela, hezkuntza murrizketa dezente jasaten ari baita azken urteotan. Esaterako, 2012tik ratioen handitzea, \% 20koa izan da. Zehazki, Lehen Hezkuntzan, 25 ikasle izatetik 30 izatera pasa da, eta Derrigorrezko Bigarren 
Hezkuntzan 30etik 36ra (Lera, 2015b; UGT, 2019). Irakasleen eskola-orduak ere zabaldu egin dira. Honek, irakasle gutxiagoren kontratazioa ekarri du, eta ondorioz, zailtasun handiagoak jarri dizkio irakasle lanari (UGT, 2019). Azken finean, eskola-ordu gehiago izanik, denbora gutxiago dute beste irakaskuntza jardueretarako. Horrez gain, programan oinarrituta, badiote zentroan jarraitutasun bat emateko zailtasunak aurkitu dituztela (Lera, 2015b).

\section{1. taula}

Irakasleengan programak izandako eragin nahiz zailtasunak

\begin{tabular}{|c|c|}
\hline \multicolumn{2}{|r|}{ Irakasleengan } \\
\hline Eraginak & $\begin{array}{l}\text { Erlazio metodo eta gela kudeatzeko teknika berriak ikasi dituzte (Gaskue, } \\
\text { 2019; GO6VIDEO, 2014; Lera, 2015b; Lera, 2006). } \\
\text { Positiboan oinarritzen ikasi dute (Gaskue, 2019; Josang eta Jensen, 2006; } \\
\text { Lera et al., 2006). } \\
\text { Ez dira horren estresatuak sentitzen (Josang eta Jensen, 2006; Lera, 2015b; } \\
\text { Lera } \text { et al., 2006). } \\
\text { Gelaren eredu izatearen garrantziaz ohartu dira (Josang eta Jensen, 2006; } \\
\text { Lera et al., 2006). } \\
\text { Beren jarrerak aztertzen dituzte (Gaskue, 2019; GO6VIDEO, 2014; Lera } \\
\text { et al., 2006). } \\
\text { Inkontzienteki egiten zutena kontzienteki egiten dute orain (GO6VIDEO, 2014). } \\
\text { Pertsona bezala asko ikasi dute (Gaskue, 2019; GO6VIDEO, 2014). } \\
\text { Psikologikoki hobeto sentitzen dira (Lera } \text { et al., 2006). } \\
\text { Beren lanaz harroago daude (Gaskue, 2019; Lera, 2015b; Lera } \text { et al., 2006). } \\
\text { Umoreak duen garrantziaz ohartu dira (GO6VIDEO, 2014; Josang eta Jensen, } \\
\text { 2006; Lera et al., 2006). } \\
\text { Ikasleekin dituzten harremanak hobetu dira (Lera et al., 2006). } \\
\text { Ikasleak hobeto ezagutzen dituzte (Lera } \text { et al., 2006). } \\
\text { Ikasleak beren lanaz gehiago arduratu dira (Josang eta Jensen, 2006). } \\
\text { Irakasle-ikasle kooperazio handiagoa dago (Lera } \text { et al., 2006). } \\
\text { Gurasoekin gehiago kooperatzen dute (Josang eta Jensen, 2006; Lera et al., } \\
\text { 2006). }\end{array}$ \\
\hline Zailtasunak & $\begin{array}{l}\text { Zenbaitetan pentsamolde berrira ohitzeko zailtasunak izan dituzte (Josang eta } \\
\text { Jensen, 2006; Lera, 2006; Lera et al., 2006) } \\
\text { Batzuetan aurretik barneratuak dituzten jarrerak atera zaizkie (Lera, 2006; } \\
\text { Lera et al., 2006) } \\
\text { Golden ikasleak aldatzea zaila izaten da, eta aldatutakoan aurrekoak ez ahaz- } \\
\text { tea (Gaskue, 2019; Lera et al., 2006) } \\
\text { Golden uneak bilatzea zaila izaten da (Lera et al., 2006) } \\
\text { Batzuetan egoera pertsonalagatik ez da horren erraza izaten ikasle batzuen- } \\
\text { gana iristea (Gaskue, 2019; Lera et al., 2006) } \\
\text { Isilak diren ikasleei erreparatzeko zailtasunak izaten dira (Gaskue, 2019; Jo- } \\
\text { sang eta Jensen, 2006; Lera } \text { et al., 2006;) } \\
\text { Gelan zeuden liderrek beste batzuk beren lidergoa lortu zutela ikustean inbi- } \\
\text { diak egon daitezke (Lera } \text { et al., 2006) } \\
\text { Ikasle batzuek atentzioa gaizki interpreta dezakete (Gaskue, 2019) }\end{array}$ \\
\hline
\end{tabular}




\section{2. taula}

\section{Ikasleengan programak izandako eraginak}

\begin{tabular}{|c|c|}
\hline \multicolumn{2}{|r|}{ Ikasleengan } \\
\hline Eraginak & $\begin{array}{l}\text { Ikasleak beren artean gehiago ezagutzen dira (Gaskue, 2019; Josang eta Jen- } \\
\text { sen, 2006). } \\
\text { Erlazioak laguntasunean oinarrituz gelako giroa positiboagoa da (Josang eta } \\
\text { Jensen, 2006; Lera, 2015b; Lera et al., 2006). } \\
\text { Gelan kohesio handiagoa dago (Gaskue, 2019; Josang eta Jensen, 2006). } \\
\text { Ikasleak gelaren parte sentitzen dira (Gaskue, 2019). } \\
\text { Autoestimu handiagoa dute (Gaskue, 2019; Lera, 2015b). } \\
\text { Irakasleentzat garrantzitsuak direla ikusten dute (Gaskue, 2019). } \\
\text { Irakaslearekin konfiantza handiagoa dute gai akademiko nahiz pertsonaleta- } \\
\text { rako (Gaskue, 2019). } \\
\text { Irakasleen azalpenei arreta handiagoa jartzen diete (Gaskue, 2019; (Lera, Jen- } \\
\text { sen, Josang et al., 2007b). } \\
\text { Eskola doikuntza hobea dute (Lera, Jensen, Josang et al., 2007b). } \\
\text { Jarrera hobetu egiten da (Lera, 2006; Gaskue, 2019). } \\
\text { Eskola motibazioa hobetu da (Gaskue, 2019; Lera, Jensen, Josang et al., } \\
\text { 2007b; Lera et al., 2006). } \\
\text { Ikasleak beren ikasketen arduradunago egiten ikasi dute (Josang eta Jensen, } \\
\text { 2006; Lera } \text { et al., 2006). } \\
\text { Errendimendua hobetu egiten da (Lera, 2015b). }\end{array}$ \\
\hline
\end{tabular}

3. taula

Familiengan programak izandako eraginak

\begin{tabular}{l|l}
\hline \multicolumn{3}{c}{ Familiengan } \\
\hline \multirow{3}{*}{ Eraginak } & $\begin{array}{l}\text { Eskolarekiko ikuspegi positiboagoa dute (Gaskue, 2019). } \\
\text { Irakasleekin gehiago kooperatzen dute (Josang eta Jensen, 2006; Lera et al., } \\
\text { 2006). }\end{array}$ \\
\hline
\end{tabular}

Aurkeztuko den ikerketak hortaz, egoera honetan pixkanaka eskoletan indarra galtzen ari den programa honekin izandako esperientzia balioestea izango du helburu orokortzat, eta horretarako, hiru esparruetan erantzunak bilatzen saiatuko da: Zein da Golden 5 programarekin lanean aritutako irakasleek hari buruz duten ikuspegia? Zein eragin ikusi dituzte irakasleek berengan, ikasleengan edota familiengan? Nola erlazionatzen da programa hezkuntza sistemarekin? 
Sara Gaskue, Alex Ibañez-Etxeberria

\section{METODOA}

Ikerketaren diseinuari dagokionez, honek helburu esploratzailea du, gaiaren ikuspegi global bat lortzeko eraman baita aurrera. Datu kualitatibo bidez egin da hori eta zeharkakoa da, datuak momentu bakar batean bilduz. Horrez gain, horiek telefono deien bidez bildurik landa-eremukoa da.

Informatzaileen lagina osatzeko, Donostiako eta Lasarteko Berritzeguneekin, hau da, Hezkuntza Publikoko irakasle formakuntzarako eta berrikuntzarako zentroekin telefono bidez kontaktuan jarri, ikerketaren berri eman eta Gipuzkoako Donostialdea eta Tolosaldea-Beterri zonaldeko Golden 5 programarekin lan egin duten eskolen zerrendak jaso dira. Gero, eskoletara deitu eta programarekin lanean aritutako edo programarekin jarraitzen duten irakasleak bilatuz aurkitu dira ikerketa honen lagina osatzen duten 7 elkarrizketatuak. Denek programaren inguruko formakuntza jaso eta horrekin lan egin dute. Horien hautaketa, irisgarritasunari jarraikiz egin da eta irakasleen artean sexu homogeneotasuna bermatzen saiatu da (ikus 4. taula).

4. taula

Elkarrizketatuen Profilaren Inguruko Informazioa

\begin{tabular}{l|c|c|c|c|c|c|c}
\hline \multicolumn{1}{c|}{ Kodea } & E1_E & E2_G & E3_G & E4_E & E5_G & E6_E & E7_E \\
\hline Sexua & Emak. & Giz. & Giz. & Emak. & Giz. & Emak. & Emak. \\
\hline Adina & 42 & 59 & 44 & 42 & 40 & 57 & 46 \\
\hline Kokalekua & D & TB & D & TB & TB & D & D \\
\hline $\begin{array}{l}\text { Irakaskuntza } \\
\text { Urteak }\end{array}$ & 20 & 38 & 23 & 17 & 10 & 15 & 26 \\
\hline $\begin{array}{l}\text { Lanpostua } \\
\text { Tutorea }\end{array}$ & $\begin{array}{c}\text { Ikasketa } \\
\text { burua }\end{array}$ & $\begin{array}{c}\text { Tutorea } \\
\text { (LH) }\end{array}$ & $\begin{array}{c}\text { GHaklea } \\
\text { (LH) }\end{array}$ & $\begin{array}{c}\text { Thasketa } \\
\text { burua }\end{array}$ & $\begin{array}{c}\text { Tutorea } \\
\text { (DBH) }\end{array}$ & $\begin{array}{c}\text { Ingelesekoa } \\
\text { (LH) }\end{array}$ & $\begin{array}{c}\text { Ikasketa } \\
\text { burua }\end{array}$ \\
\hline $\begin{array}{l}\text { Programa } \\
\text { Egoera }\end{array}$ & $\begin{array}{c}\text { Martxan } \\
\text { Martxan }\end{array}$ & $\begin{array}{c}\text { Ez dago } \\
\text { martxan }\end{array}$ & $\begin{array}{c}\text { Martxan } \\
\text { (inertziaz) }\end{array}$ & $\begin{array}{c}\text { Irregularki } \\
\text { presente }\end{array}$ & $\begin{array}{c}\text { Minimo } \\
\text { batzuk }\end{array}$ & $\begin{array}{c}\text { Eskolan ez, gere } \\
\text { beran } \\
\text { bai }\end{array}$ \\
\hline $\begin{array}{l}\text { Inplementazio } \\
\text { urteak }\end{array}$ & 4 & $3-5$ & 2-3 & 6-7 & 3-4 & 7 & 5-6 \\
\hline
\end{tabular}


Tresnei dagokienez, ikerketa honetan 45 minutu inguruko elkarrizketa erdiegituratuen bidez irakasleek Golden 5 elkarbizitza programaren inguruan duten ikuspegia azaleratu nahi izan da. Elkarrizketa indibidual bakoitza 24 galdera irekiz osatuta egon da eta lehen eskuko informazio esanguratsua lortzea izan du helburu.

Elkarrizketaren egiturari dagokionez, lehenik, ikertzailearen aurkezpena egin eta elkarrizketaren funtzionamendua azaldu da eta, bigarrenik, galdera-erantzun bidezko informazio bilketa burutu da. 4 ataletan banatu da hau: Irakaslearen testuinguru akademiko-pertsonala (4 galdera), Hezkuntza eta elkarbizitzarekiko ikuspegia (6 galdera), Programarekin izandako esperientzia pertsonala (9 galdera) eta Programarekiko ikuspegia (4 galdera). Azkenik, egindako galderez gain informazio berriren bat gehitzeko aukera eman da (ikus 2. eranskina).

Erabilitako prozedura, behin berritzegunekoek irakasle zerrenda helarazita, pertsona horiekin harremanetan jarri eta prestutasuna adierazitakoekin aurrez aurre biltzeko intentzioa bazegoen ere, COVID-19a dela eta telefono-deien bidez egin behar izan dira elkarrizketak. Hortaz, email bidez elkarrizketaren nondik-norakoak argi izateko, galderak eta baita baimen informatua ere pasatu zaizkie (ikus 3. eranskina), eta ondoren, elkarrizketa data finkatu da. Deian, ikertzaileak bere burua aurkeztu eta ikerkuntza gaia eta elkarrizketatuekiko ikertzaileak hartuko dituen konpromisoak gogorarazi dizkie. Datuak biltzeko asmoz, deia audioz grabatu da. Jarraian, horiek transkribatu, anonimotasuna bermatzeko erreferentziak jarri (E(elkarrizketa) 1(zenbakia)_E/G(sexua)) eta NVIVO programarekin burutu da analisia. Azkenik, lortutako emaitza eta horien interpretazioak irakasle parte-hartzaileei helarazi zaizkie.

\section{EMAITZAK}

Hasiera batean lau kategoriatan banatu da elkarrizketa, baina esan beharra dago ikerketaren emaitzetan elkarbizitzaren garrantziaz ( 9 erreferentzia), programaren ikuspegiaz (64 erreferentzia) eta programak irakasleengan (18 erreferentzia), zein ikasleengan (30 erreferentzia) izandako eraginez galdetu bazitzaien ere, hasierako elkarrizketetan familiengan izandako eraginez (6 erreferentzia) eta hezkuntza sistema eta programaren arteko harremanaz ( 24 erreferentzia) galdetu gabe aritu zirela elkarrizketatuak. Hortaz, ondorengo elkarrizketetan gai horiek ere jorratu dira. 
Sara Gaskue, Alex Ibañez-Etxeberria

5. taula

Golden 5 programaren inguruko sistema kategoriala

\begin{tabular}{|c|c|c|c|c|c|}
\hline Dimentsioa & Kategoria & Subkategoria & $\begin{array}{l}\text { Elkarrizketa } \\
\text { kopurua }\end{array}$ & $\begin{array}{c}\text { Erreferentzia } \\
\text { kopurua }\end{array}$ & $\%$ \\
\hline \multirow{10}{*}{$\begin{array}{l}\text { Golden } 5 \\
\text { elkarbizitza } \\
\text { programa }\end{array}$} & $\begin{array}{l}\text { Elkarbizitzaren garran- } \\
\text { tzia }\end{array}$ & & 7 & 9 & 5,97 \\
\hline & Programaren ikuspegia & & 7 & 64 & 42,38 \\
\hline & & Garrantzia & 7 & 22 & 14,57 \\
\hline & & Alderdi teorikoa & 7 & 7 & 4,63 \\
\hline & & Inplementazioa & 7 & 35 & 23,18 \\
\hline & $\begin{array}{l}\text { Programaren eragin per- } \\
\text { tsonalak }\end{array}$ & & 7 & 54 & 35,76 \\
\hline & & Irakasleengan & 7 & 18 & 11.92 \\
\hline & & Ikasleengan & 7 & 30 & 19,87 \\
\hline & & Familiengan & 4 & 6 & 3,97 \\
\hline & $\begin{array}{l}\text { Hezkuntza sistema eta } \\
\text { programaren arteko ha- } \\
\text { rremana }\end{array}$ & & 7 & 24 & 15,89 \\
\hline Guztira & & & 7 & 151 & 100,00 \\
\hline
\end{tabular}

Honako hauek dira elkarrizketetatik ateratako emaitzak (ikus 4. Eranskina):

Elkarbizitzaren inguruan irakasle guztiek diote argi dutela nola elkarbizitza eskolaren egunerokotasunean nahita ez ematen den zerbait den.

«Tokatze zaigu ikasturte bat o bi elkarrekin egotea. Ordun, hor sartzea ya elkarbizitza bat (...).» (E4-E)

Hortaz, irakasle guztientzat, hezkuntza prozesuan eskolan elkarbizitza lantzea eta presente izatea oinarrizkoa dela ikusi da, eta haien iritziz, oso zaila izango litzatekeela hori egoki landu eta barneratua izan gabe ikasleek aurrera egitea.

«Ba ikaragarria. (...) bira, elkarbizitza da gauza inportanteena eskola barrun, eta horren barrun, elkarbizitzan barrun sufritzen ai dien umeen arazoak... inor ez dutelako, edo par iten dietelako, edo bullyinga, nahi 
dezun bezela deitu, oi da lehenego arazoa eskolan. Arazo larriena. Arazo uste deun baino ugarigoa, eta horrek izugarrizko ondorioak ditu. Hoiek, ume hoiek ez dia aurrera aterako ez bazaie buelta ematen...» (E2-G)

Programaren garrantziari dagokionez, haurrak hezteko helburuan duen eragin handia azpimarratzen dute batzuek, ahalmen handikoa dela, oinarrizkoa.

«(...) nik hau baino potenteagorik ez det ikusi, argi eta garbi. (...) Hau da neretzat oinarri-oinarria, eta honen gainean hasi beste guztiarekin.» (E3-G)

Zehazki, hainbat irakaslek Golden 5ek duen filosofiaren indarra aipatu dute indargune bezala eta nola filosofia honek eskoletan gogoeta jarrera bultzatu duen.

«(...) nik uste asko duela filosofiarena, eta nik uste det bizitza hone$\tan$ filosofia oso garrantzitsua dela. Jartzen gaitu gure lekuan eta askotan nahiz eta ez bete Golden 5 ak esaten duen guztia eta gauza batzuekin batzuk ez dauden ados, beste batzuk bai, baina izan duen eztabaida eta sortu duen gogoeta guztia eskertzekoa da.» (E-1E)

Filosofia honen barnean, haurrari pertsona dimentsioa ematen zaiola ere azpimarratu da, bai haurra eta baita ingurukoak ere modu naturalean zaintzen dituela. Azken finean, irakasle hauek hezkuntzaren erdian jartzen dute ikaslea, eta programa honek, ikaslearen pertsona garapenean laguntzen duela diote.

«Ikasleari pertsona dimentsioa ematea datorrela, pertsona bat bezela ikustea dator eta horri garrantzia ematea.» (E5-G)

«Ez dakit nola esan, da amable bezela, hitza hori da, amable. Umearekiko, irakasleekiko, harremanarekiko, da atsegina, ez da gauza bat hotza, ez da gauza bat estruktura haundia dauakana edo... Ez, da zerbait naturala.» (E6-E)

Irakasleen iritziz, teoria asko jasotzen dute eskoletan, baina zenbaitetan teoriak dioen hori aurrera eramateko estrategiak dituzte faltan. Programa honek teoria lantzeko estrategiak planteatzen ditu, eta hori, indargunetzat hartu dute.

«Programaren indargune nagusia jarraitzen det pentsatzen duela alderdi bat teorikoa, eta beste bat dela oso praktikoa (...). Teoria asko jasotzen degu, baina askotan estrategietan arazoak izaten ditugu hain zuzenduak izateko.» (E1-E) 
Programaren alderdi garrantzitsuen artean ikasleez gain, familiak ere kontuan hartzen dituela aipatu eta honek duen garrantzia handia adierazi dute zenbait irakaslek.

«Familiak ditu kontuan eta familiena oso inportantea da.» (E2-G)

Irakasle guztiek programak proposatutako alderdi teorikoak oso egokiak direla adierazi dute. Oso osatuta dagoela deritzote, ikaslearen sistema guztia hartzen baitu kontuan.

«Jo neretzat oso oso konpletoa da, ikutzen ditu gauza asko eta hori da programak duen alderik potenteena nere ustez.» (E3-G)

Inplementazioari dagokionez, prozesu osoan zehar ikasle guztiei eragiteko aukeran laguntzen duela diote. Horrez gain, programak inplementazioan gidatzeko balio duten pista dezente dituela aipatu dute.

«Bost ikasle aukeratzearena neretzat da puntazo bat, porque ziurtatzen dezu denek jasotzen dutela zerbait, ze bestela beti fijatzen zea nabarmentzen den horretan ezta? edo oso ona delako edo oso txarra delako, eta beti beraiek eramaten dituzte adierazpen guztiak, eta hor badaude ikasle asko ere baita ere jaso beharko dutenak eta merezi dutenak.» (E3-G)

«(...) ba etortze zaizu zerrenda bat izen batzukin ba hau ta beste ta beste, ta hau zer da? ta nola iten da? baino ematen zitzaizkigun pista dezente.» (E2-G)

Nahiz eta inplementazioa orokorrean ona iruditu, gehiengo handi batek datuak erregistratzeko orduan izan ditu zailtasunak. Tutorea izateak eragina izan dezake horretan. Adibidez, Gorputz Hezkuntzako irakaslea egunean zehar talde ezberdinekin aritzen da lanean, eta horrek, irakaslearen lana zaildu dezakeela aipatu du.

«Inplementazioa ondo, bai, bai, ondo dago, bakarrik erregistratze hori...» (E5-G)

«Zailtasuna hombre, nik uste zailtasun nabarmenena zala hori, erregistroa eramatearena eta hori sistematizatuta txukun eramatearena. Bai, neri ere hori oso zaila egiten zitzaidan, klase bat daukazu bestearen atzetik... Igual tutore batentzat errexagoa izan daiteke, ez dakit...» (E3-G)

Bestalde, Golden 5en inplementazioa uneoro presente izan beharreko zerbait izanik, zenbaitetan kontuan hartzea zaila egiten dela deritzote, eguneroko jardunean ahaztu egin daitekeela, bai ikasle batzuk kontuan hartzea, 
edota, baita funtsezko urratsen baten aplikazioa ere. Hauek diote gehienbat diskretu edo isilagoak diren ikasleen kasuetan (programan «ikasle gris» izendatutakoetan) dela nabariagoa hau.

«Agian aitzakia da, baina gauza asko sortzen direla eta batzuetan jo honi ez diot egin, honi... (...) edo aste hontan ze gutxi, edo bakarrik hau... eta bestetan hobeto.» (E6-E)

«(...) batenbati seguro ez diozula ezer esaten ona. Batzuk eskapatzen zaizkizu grisagoak direlako, isilagoak edo ezkutatzen direlako ez dutelako ziurtasun haundirik (...).» (E3-G)

Horrez gain, eskema erreaktibo horretan berriro ere ez erortzeko eta erregistratze nahiz jarraipena era errazago batean eramateko, proiektuari espazio bat eskaintzearen, irakaslearen burua landuta izatearen eta disziplina edukitzearen garrantzia azpimarratu dute.

«Azkenean ez bazaio espazio bat ematen egunerokoan proiektuari oso zaila da egitea.» (E3-G)

«Pertsonak bere burua landua izan behar du (...) zu ez bazaude adi segitun automatikoa etortzen zaizu berriz ere.» (E5-G)

«Aurrera eramatea konszienteki eta pauta batzuk jarraituta eta hori ez? pixka bat horretan nik uste bai eduki behar duzula disziplina pixkatxo bat.» (E6-E)

Irakasleek programa nahiko zehatza, baina era berean irekia dela deritzote, eta hortaz, erregistro zailtasun horiek arintzeko, inplementazio modua moldatu dutela, bai jarduera edota prozedura ezberdinak proposatuz eta beteaz, eta baita behin dena barneratua izanik sistematizaziorik gabe jokatuz ere.

«Nik uste dut ere uzten duela pixka bat zuk zure moduan egiten ere ez? osea kontuan edukita ikuspegi hori orokorra nola planteatzen den eta hori ba egin dezakezu eta aukerak dituzu. Igual honetan probatuko dut honekin, edo probatuko dut horrela...» (E6-E)

«Guk pasa degu agenda erabiltze horretatik bakoitzak bere apunteak hartzera umeei buruz eta gero pasa ginan ya kuadro bat egitera non $\mathrm{X}$ bat jarri behar zuten ziurtatzeko betetzen zituztela gako horiek pertsona horrekin.»(E1-E)

«Ebaluaketan zehar behatz guztiak landu ote zitezkeen pentsatzen aritu nintzan eta zein zan epokarik hoberena (...).» (E5-G)

«Nik uste det Golden 5ekin oso kontzientziatuta gaudela, baina ez degula hola aplikatzen modu sistematikoan hau horrela ta horrela... baino bai daukagula begirada hori.» (E5-G) 
Azkenik, esan beharra dago inplementazio honetan laguntzeko ere ia ezinbestekotzat ikusten dutela talde lana, prozesua asko errazten baitu honek.

«Baino gero baldinbaukezu aholkulariekin harreman politta, harreman ona, sendoa, gehi zuzendaritzaren inplikazioa, ba hor, jertse hoi josita dao.» (E2-G)

Irakasleen eragin pertsonalei dagokienean, irakasleek berek diote bai beren lanerako eta baita beren eguneroko bizitzarako ere, eragin guztiz positiboa izan duela programarekin lan egiteak.

«Neretzat desde luego oso garrantzitsua izan zan, vamos ez irakasle bezela bakarrik, pertsona bezela ere, bizitzarako ere ikuspegi hori eukitzea ba neretzako oso aberasgarria izan da.» (E3-G)

Golden 5 elkarbizitza programak irakasleengan izandako eraginez hitz egitean, beren buruari galderak planteatu eta erlatibizatzearen, nahiz aurretik jada egiten zena kontzientzia handiagoz egitearen garrantzia azpimarratu dute. Kontzientzia honek, gainera, ideia berriak bururatu, edota kontuan hartzera eraman ditu irakasleak.

«Filosofia, hausnartzeko materiala, relatibismo bat ere eman digu, erlatibizatu ditugu gauza asko.» (E1-E)

«Askotan die itten genitun gauzak edo konturatu gabe ite zianak, ta ba gero dala konzientziatzea ezta?» (E4-E)

Bestalde, positiboari garrantzia ematearen indarra ikusteak eta ikasleei irekitzearen garrantzia ikusteak eragin egin die. Irakasle askok, hortaz, jarrera eta ikasle nahiz egoeren ikuspegi horrekin eskolan askoz lasaiago daudela diote.

«Eta gero, beste ohitura bat daukauna da beti txarra kontatzekoa, hortan irakaslek espezialistak gea, bakarrik txarra kontatuz, eta hori gurasoekin genun harremanetan nik uste hori ikasi egin genula, ni barne.» (E2-G)

«Ez zea bakarrik irakaslea, zure familia badijoa, beaiek badakie... irekitzea, bai.» (E4-E)

«(...) ni askoze lasaiago negoen modu honetan eta estilo honekin.» (E3-G)

Azkenik, familiekin duten erlazioetan izandako eragina aipatu dute irakasleek. Bilerak prestatzeko garaian programak izandako garrantziaz eta 
ikasleen inguruko alderdi positiboak azpimarratzearen garrantziaz aritu dira.

«(...) bilerak prestatzeko garaien, hor nik uste asko ikasi nula, bai. Zuk esan dezakezu gauz berdina, botila erdi hutsik o erdi beteta ikusi ta hoixe da, aurkeztu zure seme-alaba erdi hutsik o erdi beteta ez? horrek ez du esan nahi tapatzezunik ta bakarrik politta kontatu, kontrakoa.» (E4-E)

Ikasleen eraginei dagokionez, irakasle guztiek diote ikasleentzat Golden 5 programaren erabilpena positiboa dela eta aurrerapen handiak ematen dituztela horri esker.

«Aurrerapen handia ematen dute, bakoitzak bere gaitasunekin, baina orokorrean nola ez.» (E1-1)

Hasteko, ikasleak eskolan eta gelan gusturago sentitzen direla diote irakasleek, eta horrez gain, jarrera hobekuntzak ematen direla, autoestimu edota autokontzeptua igota beren buruan sinesten hasten direla, aintzat hartuak, indartsu, lasai sentitzen direla eta denarekiko ikuspegi berri bat dutela. Eragin positibo horiek gainera, errendimendu akademiko hobea izatera eramaten dituztela deritzote. Hori bai, irakasleen aburuz denei ez die denak era berdinean funtzionatzen, baina ezinezkoa iruditzen zaie eragin negatiborik ikustea.

«Nik nabaritzen nituen umeak gustora, gainera eskatu egiten zidaten autonomia indartzeko eta beraiek gustora hartzen zuten.» (E1-E)

«Ba ni goatzen naiz nola baneuken ikasle bat nahiko jokabide zoroekin ta bueno, behintzat hartu nindun kurtso hasieratik ba jainko bat banintz bezela, hau da, nik esate nuna beretzako zan oso inportantea, ta ba bueno, landu behar deu hau, ta horri esker jun zan jarrera pixka bat aldatzen ta goxatzen.» (E2-G)

«Nere ustez indargune garrantzitsuena da, bat ikaslea sentitzen dala baloratue ta autoestima eta autokontzeptu aldetik indartsu eta horrek gero errexteio akademikon ebai errendimendu hobea ematea.» (E4-E)

«Positiboa, erabateko positiboa. Batzuengan, ze klaro, guztiengan ez du berdin inziditzen eta igual zuk ere ez duzu berdin inziditzen ere (...), baina ezinezkoa iruditzen zait negatiborik ikustea hau egiten.» (E6-E)

Gusturago sentitze horretan, ikasleek diote irakasleekiko duten ikuspegia aldatzen dutela.

«Ikasleek zu beste modu batera ikusten zaituzte.» (E3-G) 
Gehienbat, diskretu edo isilagoak diren horietan iruditzen zaie dela nabariena alderdi pertsonaleko aldaketa hori, hauek beren buruengan ziurtasun handiagoa lortzen baitute.

«Daukat ikasle bat, zala isil isila, txikitxoa eta beti izkutatu egiten zan, ez zun inoiz arreta deitzen ezertarako (...) eta honekin zan pasada bat, (...) ziurtasun gehiago lortu zun, gero nerekin ere hitz egiten hasi zan, oso ondo.» (E3-G)

Horrez gain, talde bezala eragin positibo garbia lortzen dela ikusten dute, hau da, talde kohesioan eta ikasgelako giroan hobekuntza ematen dela.

«Nik uste det saioan beste giro bat sortzen dala, ikuspegia hain da ezberdina ez? (...) nik uste det lehen gauza aldatzen dena dela ikasgelako giroa.» (E3-G)

«Talde kohesio eta harremanak asko lantzeia eta asko zaintzeia. Eta ordun, behin eta berriz gogoraraztea denok dauzkeu gure indartsuk, ahulagok, jo baino ze inportantea dan errespetoa ta puntu indartsu hoiek baloratzea ere bai. Bai, talde kohesioan ere bai.» (E4-E)

Azkenik, familiengan izandako eraginari dagokionez, familiekiko harremanak hobetzen direla deritzote. Azken finean, izandako bizipenen arabera, Golden 5 programaren ideiei jarraituz prestatzen badira bilerak eta gurasoek kooperazio aldia ikusten badute, beste modu batera ateratzen dira bileretatik. Ondorioz, beren iritziz, lasaitu eta konfiantza handiagoa ematen diete gero etxean beren seme-alabei.

«Gurasoak ere beste umore batez doaz etxera, bilera eta gero egiten du seme-alabari konfidantza handiagoa sentiaraztea, ez matxake batean erortzea.» (E1-E)

«(...) ikusten dunian ez zaudela bere aurka bai, ba kooperazio aldia ikusten duenian, familia hori lasaitu egiten da.» (E7-E)

Zenbaitetan, programa honen ideiak berritzaileak izanagatik, gurasoek zenbait zalantza izan dituztela ere badiote irakasle batzuek. Kontatu dute esaterako, guraso batek hasieran ez zuela ulertzen positiboan oinarritze hori, zuzenketarik gabe ez baitzen ikasten bere ustetan. Beste guraso batek eskolarekiko ez zuen batere ikuspegi positiboa eta beregana hurbildu eta dena azalduz, ikuspegia aldatu eta eskola-familia harremanak hobetzeko balio izan zuen.

«Gurasoei zaila egiten zaizkie hasieran zuzenketak (...) guraso batek esan zuen zuzentzen ez badira akatsak ez dela ikasten.» (E1-E) 
«Gero jakin nun baitare aitak eskolarekiko zula oso iritzi txarra, esperientzi txarra izan zun bere garaien ta bere eskolan auskalo zergatik... (...) etorri zan ta berekin hizketan eta bueno, engantxatu genun.» (E2-G)

Hezkuntza sistema eta programaren arteko erlazioaz ere aritu dira irakasleak. Alde batetik, zenbaitetan, korrontearen aurka doazen sentsazioarekin dihardutela adierazi dute, bai ikuspegi positibo horretatik lan egitean eta baita haurra ikaskuntzaren erdian jartzeari dagokionez. Oraindik hezkuntza akademizista dela diote, eta batzuei, horren barneratua duten eskema erreaktibo horretatik ihes egitea ere kostatu zaie.

«Ahulgunea nik uste gizartean dagoen korrontearen kontra dijoala pixka bat ez? bueno pixka bat ez, asko, eta gaur egun gehiago. (...) berriz ere negatibismora eta krispaziora eramaten gaituzte bai berriek, bai politikoen adierazpenek...» (E3-G)

«Gaur egun eskatzen diren helburuak oso akademizistak dira. (...) Bai pertsonak osatzea, ez dakit hor ari gara gaitasunak eta ez dakit zer, baina... nik uste asko teorian gelditzen dela oraindik.» (E6-E)

«Eskolan bertan ere, gu hezitu gea nolabait beste eskema erreaktibo horretan ez? (...) Eta pixka bat gure buruetan ere erresistentzia hori ere hor dago, eta segun ze irakasle dan erresistentzia hori haundiagoa da.» (E3-G)

Bestetik, irakasleek diote hezkuntza sistemak gela barruko inplementazioan zailtasunak jartzen dituela, gehienbat irakas-zama eta gelako ikasle kopuru handia izanik eta gelan irakasle gehiagoren beharra azpimarratuz.

«Ez dakit, sistemak erreztasunik ez du ematen abiadura aldetik desde luego. Azkenean, hau bera ratio bajuagoekin eta karga lektibo bajuago batekin nik uste askoz hobeto egin zitekeela. Ze klaro, sartzen badituzu bi irakasle gelan batak-bestea indartuz eta saio guztiaren ardura eraman behar ez dezunean pues errexagoa da gauza hauetan pentsatzen egotea ere bai.» (E3-G)

Horrez gain, agerian utzi dute hezkuntza sistemak nahiz eskolak asko baldintza dezakeela inplementazioa. Esaterako, metodologiak eta gelako ikasle kopuruak.

«Gero beste alde batetik degu metodologiarena, segun ze metodologia erabiltzen degun, errexago beteko ditugu Golden 5ak jartzen dituen zutabeak.» (E1-E)

«Ulertzeko baitare, giroa gure eskolan seguraski nahiko Golden dala ez? ba oaintxe bertan nik 10 ikasle dauzket, ta badakit lankide asko 24kin, 25ekin daudela, ez da berdin 1000 ikasleko eskola... gureak 100 ta gutxi ditu, ta badaude txikigok. Ordun horire ulertu behar da.» (E2-G) 
Indar handienez azpimarratzeko moduan, Golden 5 programari egin zaion jarraipen falta aipatu dute irakasleek eta horrekin erlazionaturik izan dezaketen formakuntza falta eta irakasle mugimendu handia.

«Ze azkar sartzen ditugun berrikuntzak, baino gero ze azkar ahazten zazkigun baita ere. Pena da lotura hori ez mantentzea. Irakasleak hor daude, aholkulariak eskoletan hor daude, berritzegunea hor dago, baino lotura hau galdu da. Eta gure karpetak hortxe dauzkagu, batzuk behar bada botako zituzten iada, ta oain badituzte beste batzuk, baina joe, gelako kudeaketa zenek esan du ez dala mantendu behar?» (E2-G)

«Zailena da mantentzea, berria danen normalen eoteie hezkuntzatik edo berritzegneetatik eta ba ikastarok o formakuntzak, jarraipen bat dao, baino behin ya inplementatu dala, hor izatea zailena, sistematizazio horri eustea. Ta irakasle mugimendua badao o beti hasieratik haste zea o bestela informazio transmisio hortan nere ustez galdu itea zerbait.» (E4-E)

Baina aipatu beharra dago irakasle batek dioela nahiz eta programa aurrera eramateko buru bat behar den eta nahiz eta eskoletan programa eta lan berri asko sartu, interesa izan duten irakasle asko oraindik beren kabuz ari direla horrekin lanean.

«Egia da buru bat behar dala, ta askotan programa bat sartzen dala, gero beste bat, ta denekin ezin dezu jarraitu, baino bueno, behintzat poso bat uzten badu... agian eskola bezala ez da eramaten, baina pertsona asko ari dira banaka, bere kabuz egiten.» (E7-E)

\section{EZTABAIDA}

Ikerketa honen lagina osatzen duten irakasleek argi dute nola elkarbizitza egunerokotasunean nahita ez den ematen eskolan. Hortaz, Peñalva eta Sorianok (2011) esan bezala, irakasle guztientzat hezkuntza prozesuan eskolan elkarbizitza lantzea eta presente izatea oinarrizkoa dela ikusi da, eta haien iritziz, oso zaila izango litzatekeela hori egoki eraman gabe ikasleek aurrera egitea.

Programaren ikuspegiari dagokionez, haurrak hezteko helburuan duen eragin handia azpimarratzen dute batzuek, oso positiboa dela (Lera, Jensen, Josang et al., 2007b; Lera et al., 2006). Horrez gain, zehazki, hainbat irakaslek Golden 5en filosofiaren indarra aipatu dute indargune bezala eta nola filosofia honek eskoletan gogoeta jarrera bultzatu duen. Azken hori, behar-beharrezkoa da irakasle lanean (Baña eta Zaitegi, 2016). Filosofia honetan gainera, haurrari pertsona dimentsioa ematen zaiola ere azpimarratu da, haurra zaintzen duela modu naturalean. Azken finean, Hernándezek (2002) esan bezala, ikaslea modu integralean hezi behar da, eta horretarako, garrantzitsua da honi pertsona dimentsioa ematea. 
Bergekin (2002) bat etorrita, eskolako lorpenetan hobekuntza emateko familien papera oso garrantzitsua dela diote irakasleek, eta hortaz, programaren alderdi garrantzitsuen artean familiak kontuan hartzen dituela aipatu dute.

Bestalde, ikusi ahal izan da nola irakasleen iritziz, teoria asko jasotzen duten eskoletan, baina zenbaitetan teoriak dioen hori aurrera eramateko estrategiak dituzten faltan, eta programa honek teoriaz gain, estrategia horiek eskaintzea indargunetzat ikusi dute. Hortaz, irakasle guztiek, programak proposatutako alderdi teorikoak oso egokiak direla adierazi dute, eta horrez gain, ikaslearen sistema guztia kontuan hartuz, oso osatuta dagoela diote. Inplementazioa ere egokia iruditu zaie orokorrean, eta horrek prozesu osoan zehar ikasle guztiei eragiteko aukeran laguntzen duela adierazi dute. Horrez gain, programak inplementazioan gidatzeko balio duten argibide dezente dituela deritzote (Gaskue, 2019; Lera, 2006; Lera et al., 2006; Lera, Jensen, Josang et al., 2007b). Esan beharra dago, elkarrizketatuen gehiengo handi batek erregistratzeko orduan izan dituela zailtasunik handienak, baina irakasleek programa nahiko zehatza, baina irekia dela deritzote, eta hortaz, aurrez aipaturiko zailtasun horiek arintzeko inplementazio modua moldatu dute. Bestalde, Golden 5en inplementazioa uneoro presente izan beharreko zerbait izanik, ikerketa honetan ere, zenbaitetan inplementazioa ahaztu daitekeela diote irakasleek, gehienbat diskretuagoak edo isilagoak diren ikasleen kasuetan (Gaskue, 2019; Josang eta Jensen, 2006; Lera et al., 2006). Horrez gain, eskema erreaktibo horretan berriro ere ez erortzeko (Josang eta Jensen, 2006; Lera, 2006; Lera et al., 2006), proiektuari espazio bat eskaintzearen, irakaslearen burua landua izatearen (Delval, 2013; Lera, 2015b; Peñalva et al., 2013; Wentzel et al., 2010; Baña eta Zaitegi, 2016), eta diziplina edukitzearen garrantzia azpimarratu dute. Azkenik, esan beharra dago inplementazio honetan laguntzeko ia ezinbestekotzat ikusten dutela talde lana (Lera, 2006; Lera, 2009), prozesuari indarra ematen baitio horrek.

Irakasleen eraginei dagokienez, horiek diote bai beren lanerako eta baita beren eguneroko bizitzarako ere eragin guztiz positiboa izan duela (Gaskue, 2019; GO6VIDEO, 2014). Horrez gain, beren buruari galderak planteatu eta erlatibizatzearen (Gaskue, 2019; GO6VIDEO, 2014; Lera et al., 2006;) nahiz aurretik iada egiten zena kontzientzia handiagoz egitearen garrantzia azpimarratu dute (GO6VIDEO, 2014). Kontzientzia honek, gainera, ideia berriak okurritu, edota kontuan hartzera eraman ditu irakasleak. Bestalde, positiboari garrantzia ematearen indarra ikustean (Gaskue, 2019; Josang eta Jensen, 2006; Lera et al., 2006) eta ikasleei irekitzearen garrantzia ikusteak eragin die. Irakasle askok, hortaz, ikuspegi horrekin eskolan askoz lasaiago daudela diote (Josang eta Jensen, 2006; Lera et al., 2006; Lera, 2015b; Lera et al., 2006). Azkenik, familiekiko erlazioa aipatu dute irakasleek, gehiago kooperatzen dutela haiekin (Josang eta Jensen, 2006; Lera et al., 2006). 
Ikasleengan izandako eraginei dagokienez, irakasleen aburuz, ikasleentzat Golden 5 programaren erabilpena positiboa da eta aurrerapen handiak egiten dituzte honekin (Lera, 2015a). Hasteko, ikasleak eskolan eta gelan gusturago sentitzen direla diote irakasleek, eta horrez gain, jarrera hobetzen dela (Gaskue, 2019; Lera, 2006), autoestimu edota autokontzeptu igoera emanda (Gaskue, 2019; Lera, 2015b) beren buruan sinesten hasten direla, aintzat hartuak sentitzen direla, indartsu, lasai eta denarekiko ikuspegi berri bat dutela. Eragin positibo horiek, gainera, errendimendu akademiko hobea izatera eramaten dituztela deritzote (Lera, 2015b). Hori bai, zenbait irakaslek aipatu dute denei ez diela denak era berdinean funtzionatzen, baina ezinezkoa iruditzen zaiela programarekin eragin negatiborik ikustea. Gusturago sentitze horretan, ikasleek irakasleekiko duten ikuspegia aldatzen dutela diote. Gehienbat, ikasle diskretu edo isilagoetan iruditzen zaie dela nabariena alderdi pertsonaleko aldaketa hori, horiek beren espazioa aurkitzen baitute gelan (Gaskue, 2019; Lera, Jensen, Josang et al., 2007b). Horrez gain, talde bezala eragin positibo garbia izan duela ikusten dute, hau da, talde kohesioan eta ikasgelako giroan hobekuntza ematen dela (Gaskue, 2019; Josang eta Jensen, 2006; Lera, 2015b; Lera et al., 2006).

Familiengan izandako eragina galdetu gabe aipatu dute irakasleek. Familiekiko harremanak hobetzen direla deritzote. Azken finean, ikusi dute nola Golden 5 programaren ideiei jarraituz prestatzen badira bilerak eta gurasoek kooperazio aldia ikusten badute, beste modu batera ateratzen diren familiak bileretatik (Josang eta Jensen, 2006; Lera et al., 2006). Ondorioz, beren iritziz, lasaitu eta konfiantza handiagoa ematen diete gero etxean beren seme-alabei. Horrez gain, zenbaitetan programa honen ideiak, askorentzat berritzaileak izanagatik, gurasoarengana hurbildu eta dena azalduz, eskolarekiko ikuspegia aldatu eta eskola-familia harremanak hobetzeko balio izan duela diote irakasleek (Gaskue, 2019).

Hezkuntza-sistemaren eta programaren arteko erlazioaz ere aritu dira irakasleak, hori Golden 5 programa horren indarrean ez egotearen arrazoi nagusienetakoa dela aipatuz. Alde batetik, zenbaitetan korrontearen aurka doazen sentsazioarekin dihardutela adierazi dute, bai ikuspegi positibo horretatik lan egitean eta baita haurra ikaskuntzaren erdian jartzeari dagokionez. Azken ideia horiek bat datoz Bañak Zaitegiri egindako elkarrizketan azaldutako (2016), Delval (2013) eta Hernándezen (2002) hezkuntza ikuspegiarekin, baina irakasleek oraindik hezkuntza akademizista dela diote. Batzuei gainera, irakasle lanetan barneratua duten eskema erreaktibo horretatik ihes egitea ere kostatu zaie (Lera, 2006; Lera et al., 2006). Bestetik, irakasleek hezkuntza sistemak gela barruko inplementazioan zailtasun batzuk jartzen dituela diote, gehienbat, irakas-zama eta gelako ikasle kopuru handia izanik (Lera, 2015b; UGT, 2019). Horretan laguntzeko, gelan irakasle gehiagoren beharra azpimarratzen dute elkarrizketatu batzuek. Hortaz, eskolako baldintzek asko eragin dezakete inplementazioan. Amaitzeko, indar handienez azaltzeko moduan, Golden 5 programari egin zaion 
jarraipen falta aipatu dute irakasleek (Lera, 2015b), eta horrekin erlazionaturik, izan dezaketen formakuntza falta eta klaustroaren ezegonkortasuna. Azken horri dagokionez, ezinezkoa ikusten dute irakasle mugimendua egonda eta formakuntzarik eta jarraipenik gabe, irakasle berriek programa behar den bezala menderatzea. Ikusi da, bestalde, interesari jarraikiz eta eskola edota Berritzegunearen jarraipenik gabe, oraindik irakasle batzuek beren kabuz lan egiten dutela programarekin, arrastoa utzi duela.

\section{ONDORIOAK}

Ikerketa honetan parte hartu duten irakasleen aburuz, egungo hezkuntzaren helburua ikuspegi akademizistatik haratago doala ikusi da, geroz eta garrantzia handiagoa ematen baitiote ikaslearen heziketa integralari. Horretarako, ezinbestekoa da elkarbizitza era egoki eta sakon batean lantzea, eta ikusi da nola Golden 5 elkarbizitza programa oso lagungarria izan daitekeen horretarako. Hortaz, irakasleek programarekiko ikuspegi positiboa dute, nahiz eta esan beharra dagoen orokorrean erregistroan izan dituztela zailtasun handienak. Bestalde, ikusi da nola programaren filosofiarekin lan egiteak, eragin positiboak izan dituen parte hartzaile guztiengan, gehienbat, denei lasaitasuna emanez. Zehazki, irakasleak beren burua ezagutuz eta kontzientziaz jokatuz ziurrago daude saioetan, ikasleek autoestimu erlazio eta eskola motibazio hobea dute, eta azkenik, familiek eskolarekin gehiago kooperatzen dute. Amaitzeko, hezkuntza sistemari dagokionez, irakasleek euskarri handiagoa izatea eskertuko luketeela ikusi da, hau da, bai eskola eta baita Berritzegunearen aldetik jarraipen handiagoa beharko luketeela. Horrez gain, aipatu dute gelan ikasle kopuru txikiagoa eta lan karga gutxiago izateak ere inplementazioa erraztuko lukeela.

Ikerketa honetan, irakasleen esperientziatik programaren balorazioa egin nahi izan da, hau da, horiek duten ikuspegia eta haiengan zein ikasleengan izandako eragina aztertu nahi izan da, baina prozesuan, familiaren eragina nahiz hezkuntza sistemarekiko erlazioaren gaiak ere atera dira. Hortaz, mugatzat, horiek sakontasun maila baxuagoa izan dutela aipatu daiteke, ez baitzeuden prestatuta horren inguruko galderak. Horrez gain, elkarrizketatutako profesional gehienak LHko irakasleak izanik, esperientzia azterketa hau etapa honetara mugatua geratzen da. Azkenik, adierazi behar da hezkuntza-egitasmoa balioesteko eremu teorikoan beste elkarbizitza programa batzuekin alderatuz eta baita aplikazio zehatzetan ikastetxeko dokumentuak erabiliz edota ikuspegiak beste eragile batzuekin kontrastatuz osatu daitekeela ikerketa hau.

Etorkizuneko ikerketa lerrotzat, alderdi horietan sakontzeko, ikasle eta familiek ere lehen pertsonan programaren zer-nolako iritzia duten ikertzeko, etapa gehiagotara zabaltzeko eta hezkuntza-egitasmoa zein eskoletako baldintzak zehaztasun handiagoz aztertzeko aukera uzten da irekia. 
Sara Gaskue, Alex Ibañez-Etxeberria

Horrez gain, programaren inplementazio mantentze honetan laguntzeko ikerketa posibleek garrantzia handia izango lukete, programa honen erabilera gutxituz baitoa, nahiz eta erabili dutenek positibotzat jo.

\section{ERREFERENTZIA BIBLIOGRAFIKOAK}

Avilés, J.M. (2006). Bullying: el maltrato entre iguales. Agresores, víctimas y testigos en la escuela. Amarú Ediciones.

Baña, C., eta Zaitegi, N. (2016). Entrevista a Nélida Zaitegi de Miguel: Asesora en dirección y liderado educativo. Eduga: revista galega do ensino, 72. http:// www.edu.xunta.gal/eduga/1188/entrevista/entrevista-nelida-zaitegi-miguel

Berg, Jens Petter: Utdanning 9/2002 og 84-86.or.

Buccoliero, E. (2007). Clima social. http://www.golden5.org/golden5/golden5/ programa/es/3ClimaSocial.pdf

Carbajal, P. (2013). Convivencia democrática en las escuelas: apuntes para una reconceptualización. Revista Iberoamericana de Evaluación Educativa, 6(2), 13-35. or.

Cottrell, N. B. (1975). Heider's structural balance principle as a conceptual rule. Journal of Personality and Social Psychology, 31(4), 713-720. or.

Delval, J. (2013). La escuela para el siglo XXI. Sinéctica, 40, 1-18. or.

Eusko Jaurlaritza. (2019). Bizikasi. https://ikasgunea.euskadi.eus/es/web/bizikasi/ inicio

Fernández, I. (2001). Guía para la convivencia en el aula. CrissPraxis.

Gaskue, S. (2019). Golden 5 programaren inplementazioa Aitor Ikastolan. Gradu amaierako lana. Euskal Herriko Unibertsitatea.

González, M.R. (2010). Programa golden 5: hacia la mejora de las prácticas educativas. Sociedad de la información, 23.

GO6VIDEO (2014ko azaroaren 4a). «XIII. Gipuzkoako Jardunaldi Pedagogikoak» Golden 5 Esperientziak Eskoletan. Bideo artxiboa. https://www.youtube.com/ watch?v=AJcUxddcCsE

Heider, F. (1958). The Psychology of Interpersonal Relations. Willey.

Hernández, P. (2002). Los moldes de la mente. Más allá de la inteligencia emocional. Publicaciones S.L.

Hezkuntza saila (2015). Oinarrizko Hezkuntza Curriculuma. 236/2015eko Dekretua, EJ 2. zenb.

INE. (2018). Cifras de Población/ Estadística de Migraciones. https://www.ine.es/ prensa/cp_j2018_p.pdf

ISEI-IVEI (2019). Maltrato entre iguales BULLYING 2018. https://isei-ivei.hezkuntza.net/documents/635622/2640958/Ikerbul18_Informe.pdf/7d05cd61ed13-594e-771b-51 faf1 cb4217?version=1.0

Jensen, K., Joseng, F., eta Lera, M.J. (2007a). Aprendizaje ajustado. http://www. golden5.org/golden5/golden5/programa/es/4AprendizajeAjustado.pdf

Jensen, K., Joseng, F., eta Lera, M.J. (2007b). Familia y escuela. http://www. golden5.org/golden5/golden5/programa/es/5FamiliayEscuela.pdf

Josang, F., eta Jensen, K. (2006). „GOLDEN FIVE» PROJECT REPORT». http:// www.golden5 .org/golden5/golden5/resultados/ImpactNordway.pdf 
Lera, M.J. (2006). ESTUDIO PILOTO: Resultados en España (19090-2004-1-COM1-2.1). http://www.golden5.org/golden5/golden5/resultados/PilotSpain_es.pdf

Lera, M.J. (2009). Golden 5: una intervención psicoeducativa. Servicios de Publicaciones de la Universidad de Sevilla. http://www.golden5.org/golden5/ golden5/resultados/MicroAnalisisMasAllaDelAula.pdf

Lera, M.J., Jensen, K., Josang, F., Buccoliero, E., eta Szymanska, J. (2006). GOLDEN5 RESULTS: IMPACT EVALUATION (19090-2004-1-COM-1-2.1). http://www.golden5.org/golden5/golden5/resultados/ImpactGlobal.pdf

Lera, M.J., Jensen, K., eta Josang, F. (2007). La gestión del aula. http://www. golden5.org/golden5/golden5/programa/es/1GestiondelAula.pdf

Lera, M.J., Jensen, K., Josang, F., Buccoliero, E., Szymanska, J. eta Timmermans, J. (2007a). Guía de implementación. http://www.golden5.org/golden5/ golden5/implementacion/es/guia.pdf

Lera, M.J., Jensen, K., Josang, F., Buccoliero, E., Szymanska, J., eta Timmermans, J. (2007b). G5 RESULTS: Pilot study (19090-2004-1-COM-1-2.1). http:// www.golden5.org/golden5/golden5/resultados/PilotGlobal.pdf

Lera, M.J., Jensen, K., Josang, F., Buccoliero, E., Szymanska, J., eta Timmermans, J. (2007c). Inicio y fundamentos. http://www.golden5.org/golden5/ golden5/programa/es/0IniciosyFundamentos.pdf

Lera, M.J., Jensen, K., Josang, F., Buccoliero, E., Szymanska, J. eta Timmermans, J. (2007d). Pasos claves. www.golden5 .org/programa

Lera, M.J. (2015a). Golden5: una propuesta para mejorar el desarrollo humano a través del sistema educativo (pp 83-111). En Funes J. (Koord). La educación a debate: cinco años de un ciclo. Octaedro.

Lera, M.J. (2015b). Programa Golden5 $5^{\mathrm{i}}$ : una mirada positiva al desarrollo del alumnado. Convives, 10, 15-22. or.

Moya, J. (2007). Evaluación externa del proyecto Golden5. www.golden5.org

Peñalva, A., eta Soriano, E. (2011). La resolución de conflictos en contextos multiculturales a través de la mediación. En J. J. Leiva, y R. Borrero (arg.) Interculturalidad y Escuela (97-122. or).Octaedro.

Peñalva, A., López, J-J., eta Landa, N. (2013). Competencias emocionales del alumnado de Magisterio: posibles implicaciones profesionales. Revista de educación, 362, 690-712. or.

Peñalva, A., López, J.J., Vega, A., eta Satrústegui, C. (2015). Clima escolar y percepciones del profesorado tras la implementación de un programa de convivencia escolar. Estudios sobre educación, 28, 9-28. or.

Rosenthal, R. (1991). Teacher Expectancy Effects: A Brief Update 25 Years after the Pygmalion Experiment. Journal of Research in Education, 1(1), 3-12. or.

Szymanska, J., eta Timmermans, J. (2007). Construyendo relaciones. http://www. golden5 .org/golden5/golden5/programa/es/2ConstruyendoRelaciones.pdf

UGT (2019). Horario del profesorado. Horas de enseñanza anuales (Datos OCDE y UE23 2019). Horas lectivas por CCAA. https://www.fespugt.es/images/PDF/ ensenanza/Estudios\%20e\%20Informes/estudio-horario-profesorado-2019.pdf

Weiner, B. (1985). An attributional theory of achievement motivation and emotion. Psychological Review, 92(4), 548-573. or.

Wentzel, K. R., Battle, A., Russell, S. L., eta Looney, L. B. (2010). Social supports from teachers and peers as predictors of academic and social motivation. Contemporary Educational Psychology, 35(3), 193-20. or. 


\section{ERANSKINAK}

\subsection{Marko teorikoaren kontzeptu mapa}

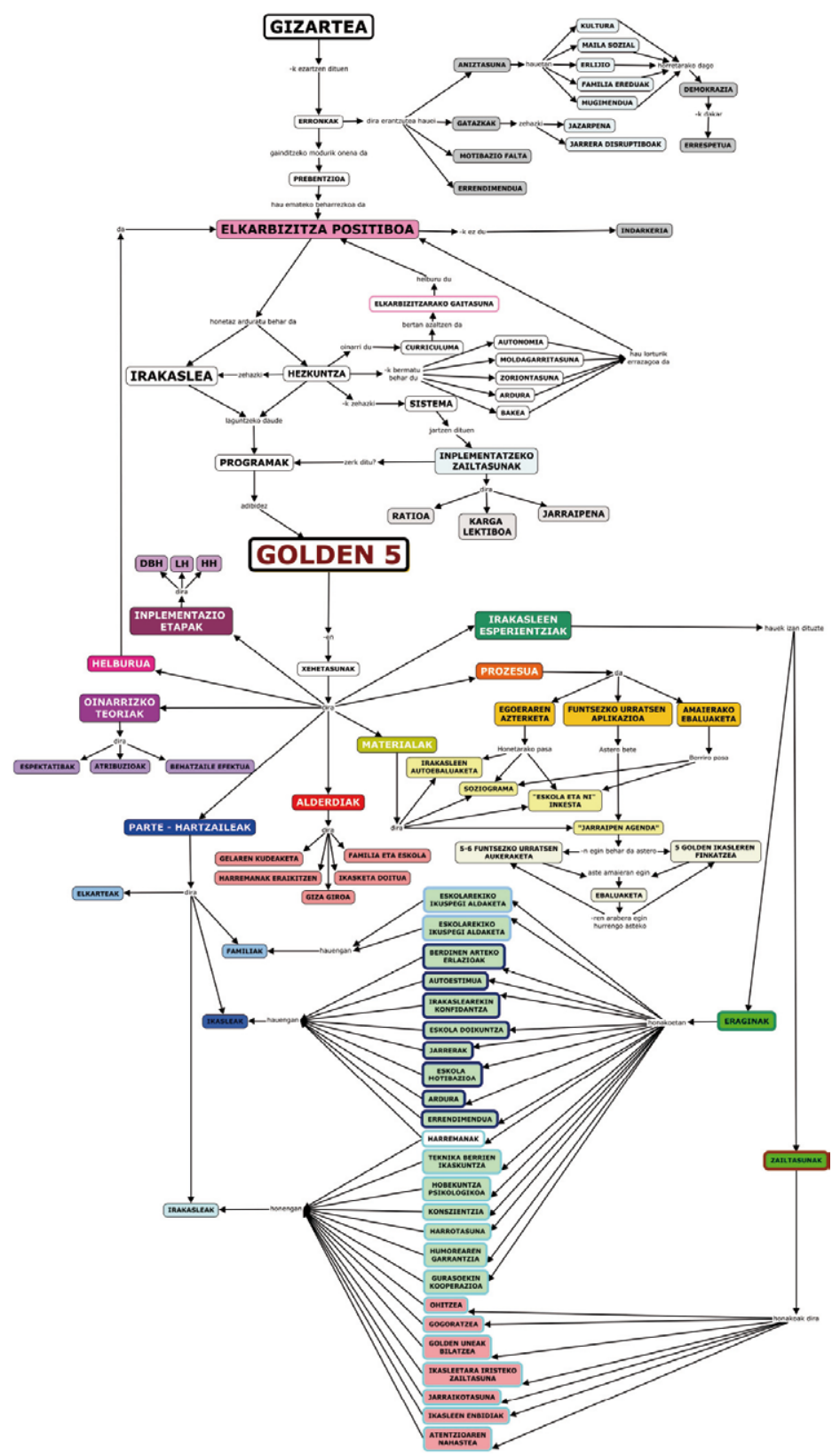




\subsection{Elkarrizketa galderak}

1. Testuinguru akademiko pertsonala:

- Nor zara? Izena, adina, nongotarra...

- Non egiten duzu lan?

- Zein da edota izan dira zure lanpostuak eskolan?

- Zenbat urte daramazkizu irakasle lanetan?

2. Hezkuntza/ elkarbizitzarekiko ikuspegia:

1. Zer da heztea zure ustez?

2. Zer da elkarbizitza zuretzat?

3. Zenbateko garrantzia ematen diozu eskola elkarbizitzari?

4. Zeintzuk dira zure ustetan gaur egun eskolak elkarbizitzari dagokionez dituen beharrak?

5. Zure ustetan gaur egun eskola eta gelak dituen elkarbizitza beharretara moldatzen da programa hau?

6. Zer uste duzu ekarri nahi duela Golden 5 elkarbizitza programak geletara?

3. Programarekin esperientzia pertsonala:

7. Zure eskolan nork erabaki zuen programarekin lanean hastea?

8. Golden 5 formakuntzetara joan zara?

9. Nola inplementatu duzu programa? Bakarrik, eskolaren euskarriarekin...

10. Zein neurritan inplementatu duzu programa? Osotasunean, alderdi batzuk bakarrik... (zeintzuk?)

11. Zenbat denbora daramazu programarekin lanean?

12. Inplementazioan zehar ikasleengan eraginik ikusi ahal izan duzu?

13. Zein eragin positibo? Zein eragin negatibo? Kasu esanguratsurik duzu gogoan?

14. Zer eragin izan du zugan programak?

15. Zein eragin positibo edota erraztasunekin aurkitu zara irakasle bezala? Zein eragin negatibo edo zailtasunekin aurkitu zara irakasle bezala?

4. Programarekiko ikuspegia:

16. Zer iruditzen zaizu programak proposatzen dituen eduki edo alderdiak?

17. Zer iruditzen zaizu programak proposatzen duen inplementazio modua?

18. Indargune garrantzitsuena?

19. Ahulgune garrantzitsuena?

5. Amaitu aurretik aurrez hitz egindakoaren inguruko zerbait gehiago gehitu nahiko zenuke? 


\subsection{Baimen informatua}

\section{Baimen informatua}

Berariaz ikerketarako bildu eta tratatutako datuak:

«Golden 5 elkarbizitza programarekiko irakasleen ikuspegi eta esperientzia» deituriko master amaierako ikerketa hau Euskal Herriko Unibertsitateako Psikodidaktika masterreko irakaslea den Alex Ibañez Etxeberriak zuzendua da. Lan eremu hau, «Enseñanza-aprendizaje de la geografia, la historia y otras ccss» ikerketa lerroan dago kokatuta.

Ikerketa honen helburua hortaz, irakasleek programarekin izandako esperientzia nahiz programa honekiko duten ikuspegia aztertzea izango da.

Datu bilketa kualitatiboki egingo da, hau da, elkarrizketa erdiegituratuen bidez burutuko da, eta horiek, gerora bere analisia egin ahal izateko, audioz erregistratu eta transkribatuak izango dira.

Elkarrizketatuari dagokionez, parte hartzea borondatezkoa izango da, ez da ikus-entzunezko materialen erabilerarik egingo, informazioarekin lan egiterakoan elkarrizketatuaren iritzi edota nahiak kontuan hartuko dira eta anonimotasuna ziurtatuko da, hori bermatzeko kode sistema erabiliz. Horrez gain, amaitzean, ikerketaren emaitzak parte-hartzaileei helaraziko zaizkie.

Zalantzarik izan ezkero sgaskue001@ikasle.ehu.eus emailera idatziz jarri zaitezke kontaktuan.

Eskerrik asko parte hartzeagatik

Izena eta abizenak:

Izena eta abizenak:

Elkarrizketatzailearen sinadura

Elkarrizketatuaren sinadura

Lekua eta data:

an

ko

(a)ren a 


\subsection{Emaitzen kontzeptu mapa}

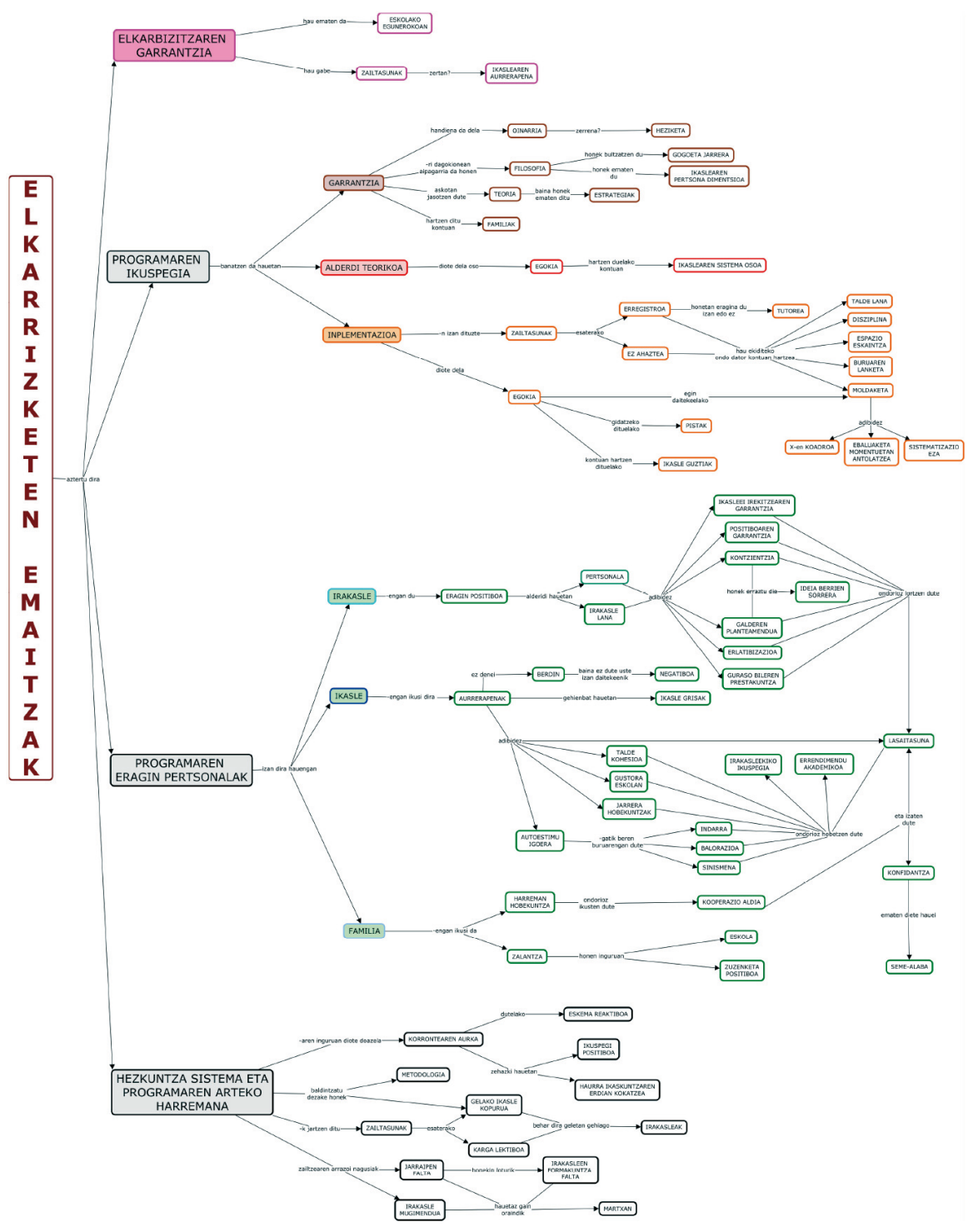

